TILTAI, 2015, 3, 25-39, ISSN 1392-3137 (Print), ISSN 2351-6569 (Online)

\title{
TINKAMA SVEIKATOS PRIEŽIŪRA: NAKTINIS MEDIKŲ DARBAS
}

\author{
Vinsas Janušonis \\ Klaipèdos universitetine ligonine, Klaipèdos universitetas
}

\begin{abstract}
Anotacija
Straipsnyje siekiama atskleisti medikų požiūrị ị naktinị darbą daugiaprofilinėse Lietuvos ligoninèse. Naktinio medikų darbo ypatumai analizuojami keliais susijusiais apibendrintais aspektais: požiūris ị naktinị darbą kaip reiškinị, naktinio darbo įtaka fiziologiniams poreikiams, sveikatai ir šeimai, naktinio darbo sąsajos su aplinka ir darbo organizacija. Atskleidžiami gydytojų ir slaugytojų požiūrių i naktinį darbą skirtumai.

PAGRINDINIAI ŽODŽIAI: sveikatos priežiūros kokybė, medikų naktinis darbas, ligoninė, saugi aplinka.
\end{abstract}

\begin{abstract}
The article aims to reveal the medics' approach to night shift work in multiprofile hospitals of Lithuania. The night shift medics' work and it singularity was analysed in several related and summarized aspects: approach to night shift work as a phenomenon (1), the impact of night shift on the physiological needs, health and family (2), the interface of night shift work with the environment and work organization (3). The differences of approaches of doctors and nurses to night shift work were disclosed in the article.

KEY WORDS: healthcare quality, medics' night shift work, hospitals, safety environment.
\end{abstract}

DOI: http://dx.doi.org/10.15181/tbb.v72i3.1164

\section{Ivadas}

Naktinis darbas išskirtas ir įstatymiškai apibrěžtas jau XIX amžiuje (1919 m.) tarptautiniuose darbo standartuose. 1990 metais priimta tarptautinè naktinio darbo konvencija.

Naktimis dirba daugiau kaip 5 proc. visų dirbančiujų visu krūviu (Kryger, et al., 2005). Naktinis darbo laikas paskirose šalyse ir organizacijose nustatomas įvairus, tačiau dažniausiai yra nuo septintos valandos vakaro iki aštuntos valandos ryto.

Mediko (gydytojo, slaugytojo) profesija - viena labiausiai su naktiniu darbu susijusių profesijų. Pacientai ligoninèse tiriami, gydomi ir prižiūrimi tiek dieną, tiek naktį. Ligos, nelaimingi atsitikimai ịvyksta bet kuriuo paros laiku. Ligoninèse besigydantys pacientai pusę laiko ten prabūna naktị. Juos medikai turi prižiūrèti, gydyti, suteikti skubią medicininę pagalbą. 
Naktinis medikų darbas netapatus dienos darbui. Jam būdingi tam tikri ypatumai ir kontraversijos, specifinès problemos.

Mokslininkai naktinį darbą dažniausiai tyrinejja trimis aspektais:

- pacientų;

- medikų;

- organizacijos.

Pacientų sveikatos priežiūra naktị pasižymi savo specifika, tai susiję su jų fiziologiniais poreikiais, saugumu, aplinka ir priklauso nuo juos prižiūrinčių medikų komandos, kurioje viena svarbiausių grandžiu - slaugytojai (Smith, 2007).

Laikytis nustatytų pacientų priežiūros standartų naktị daugeliui medikų dèl naktinio darbo specifikos nelengva, todèl nuo jų neretai nukrypstama (Mueche, 2005). Slaugytoja naktị pacientams atlieka vidutiniškai 51 veiksmą (leidžia vaistus, keičia tvarsčius, patalynę, tenkina pacientų fiziologinius poreikius ir kt.). Intensyvios terapijos ir reanimacijos skyriuose medikų kontaktai su pacientais dar dažnesni (Celik, 2005).

Pacientų sveikatos priežiūros rezultatai, kokybė, jų saugumas, ypač naktį, labai priklauso nuo paciento dalyvavimo savo sveikatos priežiūros procese. Pacientas savo sveikatos istoriją, jos pokyčius, ypatumus žino puikiai, todėl labai svarbu ji įtraukti ị sveikatos priežiūros procesą (Lee, Lin, 2010; Doyle, et al., 2013). Dauguma pacientų noriai šiame procese dalyvauja. Tokių pacientų sveikatos priežiūros kokybė yra geresnè, nepageidautinų įvykių ịvyksta mažiau (Weingart, et al., 2011).

Pagrindinis pacientų fiziologinis poreikis naktį - miegas. Atvykęs ar atgabentas ị ligoninę pacientas patenka ị jam neịprastą aplinką, ypač naktį. Palatoje jis dažniausiai yra ne vienas, taigi turi prisitaikyti prie kitų poreikių. Nakti pacientai neretai guldomi i palatas, kur yra vietų. Šiuo paros metu kai kuriems pacientams būtina atlikti procedūras, dalis jų prastai miega dẻl esamos sveikatos būklès, skausmų, tai veikia kitus.

Svarbu patenkinti individualius pacientu maisto, troškulio numalšinimo poreikius, suteikti galimybę prireikus pasinaudoti tualetu ar patenkinti fiziologinius poreikius palatoje (nevaikštantys pacientai). Svarbu atsižvelgti ị tai, kad pačių pacientų poreikių tenkinimo vertinimas skiriasi nuo medikų vertinimo (Oleni, et al., 2004).

Pacientų sveikatos priežiūra naktị, jų miegas glaudžiai susiję su triukšmu, kaip vienu svarbiausių aplinkos veiksnių. Triukšmas pacientams trukdo miegoti, veikia kaip stresorius, gali padidinti kraujo spaudimą. Triukšmas gali būti ekstrahospitalinis (mašinos, autobusai, netoliese esantys barai, restoranai, parduotuvès) ir intrahospitalinis (personalas, pacientai, lankytojai). Triukšmo, ypač intrahospitalinio, prevencijai svarbus ligoninės padalinių išdėstymas, personalo avalynė, procedūrų tvarka, savalaikis televizorių, radijo imtuvų išjungimas, pacientų dienotvarkès ir 
režimo laikymasis, kitos priemonės. Triukšmo prevencija turi būti numatyta veikiančiose ligoninių kokybės sistemose.

Naktị ligoninèse padaugèja ịvairių kriminalinių ịvykių - vagysčių, chuliganiško elgesio, kuris susijęs su alkoholio ar kitų svaiginamųjų medžiagų vartojimu, lytinių nusikaltimų. Tai susiję tiek su lankytojais, tiek ir su pacientais. Svarbi saugi inžinerinè ir techninè aplinka.

Naktinis medikų darbas turi įtakos pacientų saugumui ir jų sveikatos priežiūros kokybei. Ši ịtaka pasireiškia didesniu nepageidautinų įvykių ir medicinos klaidų skaičiumi dèl naktinio darbo ypatumų, streso (Janušonis, 2005; 2008).

Medikų asmeninis naktinio darbo aspektas apima jų kvalifikaciją, fiziologinius poveikius, adaptaciją, aplinką, socialinius ir rizikos veiksnius, specialiąsias sąlygas.

Siekiant naktinį medikų darbą ,priartinti“ prie dieninio, turima galvoje medikų kvalifikacija (žinios, patirtis, ịgūdžiai), atsakomybẻ ir rezultatai, būtina keisti ne tik specialistų rengimą, bet ir pačią sveikatos sistemą bei visuomenę, svarbus integruotas požiūris ị nenutrūkstamą sveikatos priežiūrą (Khoddam, et al., 2014).

Vis dèlto net ir idealiais atvejais naktinis medikų darbas niekada nebus tapatus dieniniam. Naktị didesnès skubios hospitalizacijos apimtys, daugiau komplikacijų ir medicininių klaidų, daugiau pacientų mirčių (Miller, 2010; Hendey, et al., 2005). Todẻl nemažai diskutuojama dẻl jaunų medikų (rezidentų, trejus metus darbo patirties turinčiu gydytojų, slaugytojų) darbo ir jo rezultatų naktį, kokios jų galimybės priimti teisingus sprendimus, mokytis ir tobuleti (Campbell, et al., 2008; Galagher, et al., 2009; Dalton , 2013; Novoselsky-Persky, 2013; Coomber, 2014).

Pažymima, kad pačiam patirti naktinio darbo ypatumus ir sužinoti tai iš kolegų ar vadovų, nėra tas pats. Patyrimas vertingas, jeigu formuojamas ịvairiais būdais: teorines žinias derinant su praktiniu patyrimu ir darbu komandoje.

Fiziologiniai poveikiai - tai visų pirma cirkadinio paros ritmo ir melatonino apykaitos sutrikimas. Jie susiję su miego, valgio, poilsio normalaus ritmo sutriki$\mathrm{mu}$ ir jo pasekmėmis. Naktinio ir dieninio medikų darbo pamainų rotacija padeda išvengti ilgalaikio miego sutrikimo, padeda greičiau grąžinti fiziologinị ritmą (Niu, 2012; Ruggiero, Redeker, 2014). Aktualiausias ir plačiausiai nagrinejjamas aspektas - miego ritmo sutrikimai ir galimos to pasekmès. Nepakankamai išsimiegoję gydytojai daro daugiau medicininių klaidų nei pailsèję (Landrigan, 2004; Van Dongen, 2003). Vieną naktị dirbusio ir dieną nemiegojusio gydytojo psichomotorinè veikla panaši ị žmogaus, kurio alkoholio koncentracija kraujyje yra 0,1 proc. (Arnedt, et al., 2005), tai yra 2,5 karto daugiau, nei leidžiamas alkoholio kiekis kraujyje vairuojant Lietuvoje. Miego trūkumas gali lemti kai kurių ligų ar sindromų atsiradimą. Mitybos ritmo sutrikimas dirbant naktinį darbą gali lemti virškinimo organų disfunkciją, nutukimą, gliukozès kiekio pokyčius kraujo seru- 
me, hormoninius sutrikimus. Todèl mitybai dirbant naktinį darbą reikia skirti daug dẻmesio - ateiti ị darbą pavalgius, vartoti skysčių, valgyti mažiau baltymų ir riebalų turintị maistą. Būtina riboti stimuliuojančių gèrimų (kavos, arbatos, energinių gėrimų) vartojimą, juos vartoti mažomis dozėmis.

Vienas iš naktinio darbo fiziologinio poveikio pasekmių - galima jo įtaka tam tikrų ligų atsiradimui. Tačiau ši prielaida kelia daug diskusinių klausimų (Burgerd, Lin, 2013). Dažniausiai minimos galimai su naktiniu darbu susijusios ligos: išeminè širdies liga, krūties vėžys, kolorektalinis vėžys, afektiniai susirgimai, kitos širdies ligos, diabetas, hipertenzija, plaučių ligos ir vėžys, nèštumo patologija. Vis dèlto mokslinių tyrimų rezultatai labiau paneigia nei patvirtina šių ligų ir naktinio darbo sąsajas (galbūt išskyrus kai kuriuos afektinius sutrikimus ir neeštumo patologiją).

Kai kurie autoriai nurodo, kad ligas dažniau lemia gyvenimo būdas ir rizikos veiksniai, o ne naktinis darbas (Fujino, et al., 2006). Tačiau neatmetama, kad dirbant naktinị darbą ilgesnị laiką, rizika susirgti tam tikromis ligomis galimai didesnè.

Vèžinių susirgimų ir naktinio darbo galimos sąsajos siejamos su melatonino apykaita (jo sumažèjimu) (Schernhammer, et al., 2003), hipertenzija - su stresu ir nuovargiu (Bacon, 2014).

Adaptacija - tai realus individo (mediko) atsakas ị naktinị darbą, kaip realų fenomeną, nenumatytą (nenormalią) patirtį. Tai prisitaikymas prie tamsos, naktinio darbo aplinkos ir ypatumų, miego ir mitybos pokyčių. Tai susiję ir su socialine adaptacija - profesinès veiklos ir asmeninio gyvenimo (šeimos, laisvalaikio) derinimu. Naktinis mediko darbas iš dalies veikia partnerio (sutuoktinio), vaikų ir draugų gyvenimo ritmą.

Dirbant naktị (nagrinejjamu atveju - medikams) iš dalies išsitrina laiko suvokimo ribos, jo pojūtis: nebelieka griežtų ribų tarp privataus ir viešo, namų ir darbo, tarp buvusio, esamo ir būsimo laiko. Tai paaiškinama tuo, kad žmogus laiką suvokia ívykių ir vietos pakeitimo prasme (dažniausiai prieš (iki) ir po). Dèl to vyresniesiems (medikams) laikas (taip pat ir dirbant naktị) bèga greičiau, nei jaunesniesiems (Braun, Brooks, 2002).

Darbo aplinka (apšvietimas, galimybė pailsèti ir pavalgyti, darbo įrankiai ir priemonès) turi ịtakos medikų pasitenkinimui darbu, mažina naktinio ir dieninio darbo skirtumus, gerina sveikatos priežiūros paslaugų kokybę, mažina nepageidautinų îvykių ir klaidų riziką (Janušonis, 2005; Ulrich, 2005; Dumont, 2009).

Rizikos veiksniai dirbant naktinị darbą susiję su fiziologiniais poreikiais (miegas, mityba, asmens higiena ir kt.), aplinka (tamsus paros laikas, triukšmas), darbo krūviu, komandiniu darbu. 
Socialiniai veiksniai - tai darbo naktị ir šeimos, artimujų poreikių derinimas. Jie daro didelę ittaką darbo naktị pasirinkimui ir parinkimui, darbo grafikų sudarymui.

Problemos ir konfliktai šeimoje, skyrybos - galimos naktinio darbo pasekmès (Marsholl, Tracy, 2009; Hochschild, Machung, 2012).

Specialiosios sąlygos - vienas svarbių naktinio darbo aspektų. Karo, kalejjimo, psichiatrijos ligoninėse ir skyriuose, intensyvios terapijos ir reanimacijos, vaiku skyriuose naktinis medikų darbas yra specifinis: naktị šių pacientų poreikiai ir jų sveikatos priežiūra yra specifinè, reikia turèti specialių žinių, patirties, igūdžių, remtis nustatytomis instrukcijomis. Visa tai ịgyjama per tam tikrą laiką, tai gana ilgas procesas.

Naktị ir išeiginėmis dienomis ị ligonines guldoma iki 70 proc. pacientų, tačiau naktị dirba tik apie 6 proc. visų ligoninèse dirbančių gydytojų (Landro, 2008). Sveikatos priežiūros organizacijos (ligoninès) aspektu naktinis darbas susijęs su darbo organizavimu, organizaciniu stresu, aplinka, sąnaudomis.

Naktinio darbo ligoninejje organizavimas apima keletą momentų:

- naktinio darbo „karštujų“ (rizikos) pozicijų nustatymas (hospitalizacija, operacinè veikla ir kt.);

- padalinių ir žmonių tarpusavio sąveikos ịvertinimas (vadovai, atsakingi asmenys, rezervinès medikų brigados ir kt.);

- instrumentų sprendimams priimti suradimas ir dokumentavimas (ištekliai, darbo grafikai, darbo protokolai, tvarkos ir kt.);

- sprendimų prièmimas (darbo grafikų sudarymas, vadovų [atsakingų mediku] paskyrimas, rezervinių brigadų sudarymas, išteklių paskirstymas ir kt.);

- sprendimų rezultatyvumo ịvertinimas (dokumentų analizè, klausimynai medikams ir pacientams).

Naktinè hospitalizacija paprastai yra skubi, neatidèliotina, ne planinè. Su tuo susijęs operacinès veiklos organizavimas, diagnostika, intensyvi ir reanimaciné pagalba. Padalinių ir žmonių tarpusavio sąveika įvertinama vertinant veiklą (pakankama ir atitinkanti reikalavimus, nepakankama ir neatitinkanti reikalavimų), jos rezultatus (nepageidautinus ịvykius), informaciją ir jos perdavimą (pakankama, nepakankama, teisinga, neteisinga), išteklių paskirstymą. Veiklos dokumentavimas yra vienas svarbių sprendimų prièmimo instrumentų.

Organizuojant medikų naktinị darbą svarbu parengti darbo grafikus, atsižvel-

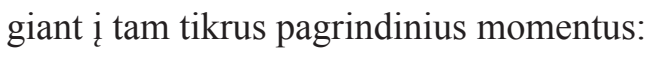

- tik naktinị darbą dirbančių medikų išskyrimas ar kintamas darbo grafikas;

- daugiau ar mažiau patyrusių medikų skyrimas dirbti naktį; 
- naktinio darbo „komandų“ formavimas;

- darbo laiko trukmé;

- poilsio režimas;

- atsižvelgimas (neatsižvelgimas) į medikų pageidavimus dirbti (nedirbti) naktinị darbą.

Daugelyje ligoninių medikai dirba 24 valandų pamainą, tačiau nemažai slaugytojų dirba tik naktị (Campbell, 2008). Lietuvoje 24 val. pamainos leidžiamos tik budintiems gydytojams.

Vienas organizacinio streso aspektų yra darbo stresas, o vienas iš darbo streso aspektu - naktinis darbas. Stresas gali lemti afektinius sutrikimus (pervargimą, depresiją, nerimą, nuotaikos pokyčius ir kt.), nepasitenkinimą darbu ir jo pasekmes, elgsenos ir gyvenimo būdo pokyčius, priklausomybę nuo alkoholio, vaistų (Lucini, Pagani, 2012).

Ne tik afektiniai sutrikimai, bet ir kai kurios kitos ligos neretai siejamos su stresu, kuris galimai labiau patiriamas dirbant naktį. Neigiama streso įtaka gali pasireikšti emocinėmis reakcijomis (nerimu, pykčiu, depresija, nuotaikos svyravimais), mąstymo pokyčiais (atminties, dėmesio sutrikimai, elgsenos ir gyvenimo būdo pokyčiai) (Janušonis, Kringelytė, 2009). Afektiniai sutrikimai medikams labiau būdingi, lyginant su kitų profesijų žmonėmis (Weinberg, Creed, 2000; Wieclav, et al., 2006).

Būtini skubūs klinikiniai sprendimai, pacientu mirtys, ribotos medikų galimybès padèti kai kuriomis ligomis sergantiems pacientams, pacientų poreikių ir medikų galimybių neatitikimas didina medikų stresą ir lemia su juo susijusias pasekmes.

Darbo aplinka naktị vadybiniu požiūriu turi būti saugi, saugumą užtikrina: medikų ir pacientų apsaugos sistemos (saugos tarnybos ir kt.), kriminalinių įvykių (galimybiu nusikalsti) prevencijos programos, pacientu identifikavimas (anamnezė [buvęs laisvès atėmimas], elgsena, tatuiruotès ir kt.), inžinerinès-techninès (elektra, dujos, šildymas, vẻdinimas, liftai ir kt.), pacientų lankymo ir priežiūros, priešgaisrinès, durų rakinimo (blokavimo) sistemos ir kt.

Naktinis darbas lemia ir papildomas sąnaudas, kurias sudaro:

- personalo rengimas ir apmokymas;

- priemokos už naktinị darbą;

- personalo nepasitenkinimas ir su tuo susijęs darbo našumas bei rezultatai (Jones, 2004, 2005).

Sąnaudos iš dalies priklauso nuo požiūrio ị naktinio darbo sudètingumą ir personalo paskirstymą. Laikantis požiūrio, kad naktinis darbas yra sudètingesnis už 
dieninị ir skiriant ji dirbti labiau patyrusius profesionalius medikus (turinčius $5 \mathrm{~m}$. ir didesnị profesinį darbo stažą, baigus universitetą) - sąnaudos bus didesnès.

Darbo tikslas - įvertinti medikų požiūrị ị naktinị darbą daugiaprofilinèse Lietuvos ligoninèse.

\section{Tyrimo apimtis ir metodai}

Tyrimas suplanuotas 2014 m. 2015 m. gegužès - liepos mènesiais jis vykdytas šešiose daugiaprofilinėse Lietuvos ligoninèse.

Tyrimo objektas - medikų požiūris ị ịvairius naktinio darbo aspektus.

Tyrimo populiacija - sveikatos priežiūros paslaugas ligoninèse dieną ir naktị teikiantys medikai (gydytojai ir slaugytojai).

Tyrimo metodai: anoniminė anketinè apklausa, mokslinès literatūros analizé, statistinis duomenų grupavimas, lyginamoji analizè.

Tyrimui atlikti naudota autoriaus sudaryta anoniminė anketa (klausimynas). Klausimynas rengtas akcentuojant kelis susijusius apibendrintus aspektus: požiūrị ị naktini darbą kaip reiškini, naktinio darbo ịtaką fiziologiniams poreikiams, sveikatai ir šeimai, naktinio darbo sąsajas su aplinka ir darbo organizavimu.

Anketos įteiktos dirbantiems medikams ir grąžintos užpildytos tą pačią ar kitą dieną.

Išdalinta 430 anketų, užpildyta 419 anketų (atsako dažnis - 97 proc.). Analizuota 415 anketų (1 sugadinta, 3 respondentai nedirbę naktị).

Pakankamas imties tūris, esant ne didesnei kaip 5 proc. paklaidai, - 398 (Kardelis, 2005). Respondentų imtis pakankama.

Analizuotos gydytojų ir slaugytojų grupès pagal gyvenamają vietą, amžių, lytị, darbo profili, išsilavinimą, socialinę ir šeiminę padètị, specialybès ir naktinio darbo stažą. Tiriamujų bendroji charakteristika pateikta 1 lentelèje.

Statistinè duomenų analizė atlikta SPSS 19,0 for Windows ir Microsoft Excel 2007 programomis. Statistinių duomenų reikšmingumas tikrintas taikant Pearsono ${ }_{\mathrm{x}}^{2}$ kriterijų, laisvès laipsnių skaičių (Df), Spearmano koeficientą, Stjudent $t$ kriterijų.

Duomenų skirtumas laikytas statistiškai reikšmingu, kai $p<0,05$ (statistinio pasikliautinumo lygmuo - 95 proc.). 
1 lentele. Bendroji tiriamujų charakteristika

\begin{tabular}{|c|c|c|c|}
\hline Požymis & $\begin{array}{c}\text { Gydytojai } \\
(n=165)\end{array}$ & $\begin{array}{c}\text { Slaugytojai } \\
(n=250)\end{array}$ & $\begin{array}{c}\text { Iš viso } \\
(n=415)\end{array}$ \\
\hline $\begin{array}{l}\text { Lytis: } \\
\text { vyrai } \\
\text { moterys }\end{array}$ & $\begin{array}{l}75 \\
90 \\
\end{array}$ & $\begin{array}{l}1 \\
249\end{array}$ & \begin{tabular}{|l}
76 \\
339 \\
\end{tabular} \\
\hline $\begin{array}{l}\text { Amžius: } \\
20-29 \mathrm{~m} \\
30-39 \mathrm{~m} \\
40-49 \mathrm{~m} \\
50-59 \mathrm{~m} \\
60 \mathrm{ir}>\mathrm{m}\end{array}$ & $\begin{array}{l}4 \\
60 \\
39 \\
32 \\
30 \\
\end{array}$ & $\begin{array}{l}19 \\
50 \\
112 \\
64 \\
5\end{array}$ & $\begin{array}{l}23 \\
110 \\
151 \\
96 \\
35 \\
\end{array}$ \\
\hline $\begin{array}{l}\text { Gyvenamoji vieta: } \\
\text { miestas } \\
\text { kaimas }\end{array}$ & $\begin{array}{l}144 \\
21\end{array}$ & $\begin{array}{l}226 \\
24\end{array}$ & $\begin{array}{l}370 \\
45 \\
\end{array}$ \\
\hline $\begin{array}{l}\text { Socialine padétis: } \\
\text { pensijos gavejjas } \\
\text { neigalumas }\end{array}$ & $\begin{array}{l}26 \\
1 \\
\end{array}$ & & $\begin{array}{l}29 \\
5 \\
\end{array}$ \\
\hline $\begin{array}{l}\text { Išsilavinimas: } \\
\text { aukštasis universitetinis } \\
\text { aukštasis neuniversitetinis } \\
\text { aukštesnysis }\end{array}$ & 165 & $\begin{array}{l}76 \\
60 \\
114\end{array}$ & $\begin{array}{l}241 \\
60 \\
114\end{array}$ \\
\hline $\begin{array}{l}\text { Šeimine padètis: } \\
\text { nevedęs / netekèjusi } \\
\text { vedęs / ištekëjusi } \\
\text { išsiskyręs / išsiskyrusi } \\
\text { našlys / našle }\end{array}$ & $\begin{array}{l}28 \\
116 \\
17 \\
4\end{array}$ & $\begin{array}{l}29 \\
178 \\
34 \\
9\end{array}$ & $\begin{array}{l}57 \\
294 \\
51 \\
13 \\
\end{array}$ \\
\hline $\begin{array}{l}\text { Darbo profilis: } \\
\text { vidaus ligu } \\
\text { chirurgijos } \\
\text { akušerijos-ginekologijos } \\
\text { anesteziologijos reanimacijos } \\
\text { kita }\end{array}$ & $\begin{array}{l}43 \\
46 \\
24 \\
5 \\
47 \\
\end{array}$ & $\begin{array}{l}54 \\
54 \\
30 \\
21 \\
91\end{array}$ & $\begin{array}{l}97 \\
100 \\
54 \\
26 \\
138 \\
\end{array}$ \\
\hline $\begin{array}{l}\text { Specialybès darbo stažas: } \\
\text { iki } 5 \mathrm{~m} . \\
5-15 \mathrm{~m} . \\
>15 \mathrm{~m} .\end{array}$ & $\begin{array}{l}21 \\
57 \\
87\end{array}$ & $\begin{array}{l}17 \\
46 \\
177\end{array}$ & $\begin{array}{l}38 \\
103 \\
264 \\
\end{array}$ \\
\hline $\begin{array}{l}\text { Naktinio darbo stažas: } \\
\text { iki } 5 \mathrm{~m} . \\
\text { 5-15 m. } \\
>15 \mathrm{~m} .\end{array}$ & $\begin{array}{l}21 \\
63 \\
81\end{array}$ & $\begin{array}{l}36 \\
84 \\
130\end{array}$ & $\begin{array}{l}57 \\
147 \\
211 \\
\end{array}$ \\
\hline
\end{tabular}




\section{Rezultatai ir jų aptarimas}

Visi tirti medikai turejo naktinio darbo patirties: 13,7 proc. - iki 5 m., 35,4 proc. $-5-15 \mathrm{~m} ., 50,9$ proc. - daugiau kaip $15 \mathrm{~m}$.

Dauguma medikų (62,2 proc.) pažymejjo, kad dirbti naktį jiems ne geriau nei dieną. Gydytojų ir slaugytojų nuomonès šiuo klausimu skiriasi - tai nurodė 85,5 proc. gydytojų ir 46 proc. slaugytojų. Daugiau nei trečdalis slaugytojų (39,6 proc.) teigè, kad jiems geriau ar galbūt geriau dirbti naktị nei dieną, o taip teigusių gydytojų buvo 7,3 proc. Jeigu būtų galimybé, naktinį darbą rinktųsi ar galbūt rinktųsi 36 proc. slaugytojų ir tik 3,6 proc. gydytojų (1 pav.).

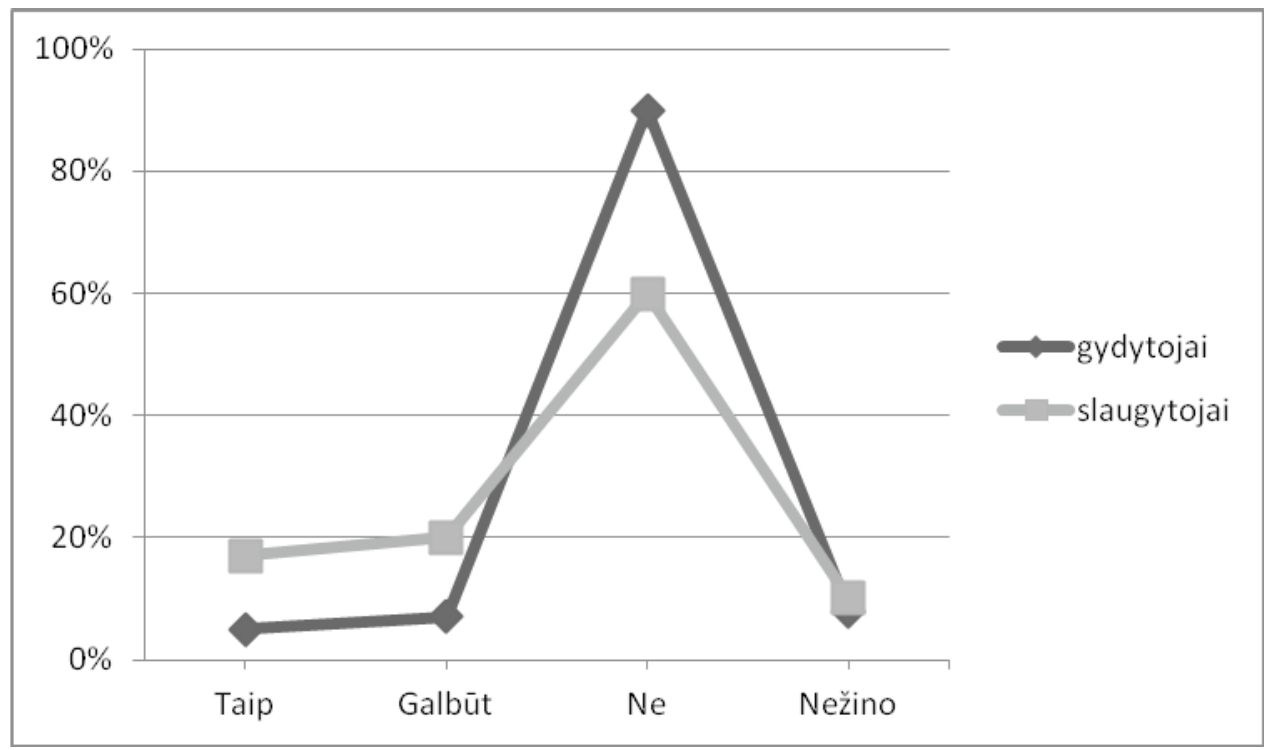

1 pav. Respondentų atsakymų ị klausimą, ar rinktųsi naktinị darbą, jeigu būtų tokia galimybè, pasiskirstymas

Daugumai slaugytojų (60,5 proc.), kurios rinktųsi darbą naktį, problemų šeimoje dèl to nekyla. Daugelio medikų nuomone, darbas naktị nèra mažiau sudètingas nei dieną ( 82,2 proc.), todẻl darbuotojų kompetencija turètų būti tokia pati (67,5 proc.) ar net aukštesnè (30,8 proc.). Kad dirbti naktinị darbą reikia didesnès kompetencijos, nurodė 39,4 proc. gydytojų ir 25,2 proc. slaugytojų. Taigi daugelis medikų mano, kad naktinis ir dieninis darbas skiriasi, naktinis darbas net sudètingesnis, jam atlikti reikia kompetentingesnių darbuotojų. Apie tai kalbama ir mokslineje literatūroje (Khoddam, et al., 2014).

Dauguma medikų (61,4 proc.) nurodè, kad nereikètų skirti dirbti tik naktimis, tačiau net 13 proc. ị šį klausimą atsakyti negalejjo. Tai, kad medikai turètų dirbti ir 
dienomis, ir naktimis, t. y. jie turètų būti rotuojami, rašoma ir literatūros šaltiniuose (Mueoke, 2005; Landro, 2008; Campbell, 2008).

49,6 proc. medikų nurode, kad neturetų skirtis ir jų pareigybių aprašymai, dirbant dieną ar naktį, 35,9 proc. - kad turètų ar galbūt turètų skirtis, 14,5 proc.negalëjo atsakyti. Šiuo klausimu gydytojų ir slaugytojų nuomonès skyrėsi: kad pareigybių aprašymai neturètų skirtis, manė 33,3 proc. gydytojų ir 59,6 proc. slaugytojų.

Medikų nuomonès dèl darbo aplinkos, aprūpinimo darbo priemonėmis ir vaistais dieną ir naktị skirtumo pasidalijo per pusę: 48,2 proc. mané, kad skirtumo nèra, 51,3 proc. - kad skiriasi ar galbūt skiriasi.

Šiuo klausimu gydytojų ir slaugytojų nuomonès nesutapo - 70,9 proc. gydytojų ir tik 38,4 proc. slaugytojų įžvelgè skirtumus tarp darbo aplinkos, priemonių bei vaistų naktị ir dieną.

Medikų požiūriui ị naktinị darbą ligoninèje, kaip reiškinị, darbo sąsajas su aplinka ir jo organizavimu, lytis, amžius, socialinè padètis, išsilavinimas, šeiminé padètis, darbo profilis, specialybès ir naktinio darbo stažas bei gyvenamoji vieta itakos neturèjo.

Analizuojant, kaip naktinis darbas veikia cirkadini ritmą, nustatyta, kad 84,1 proc. mediku naktinis darbas sutrikdo, o 8,4 proc. galbūt sutrikdo cirkadini ritmą ir kenkia (83,6 proc.) ar galbūt kenkia (12,3 proc.) sveikatai.

Gydytojų ir slaugytojų nuomonès šiais klausimais statistiškai patikimai nesiskyrè.

Tai, kad dirbdami naktị jaučia didesnę darbinę ịtampą, stresą, nurodė 60,5 proc. medikų, 12,3 proc. - kad galbūt jaučia, 36,9 proc. - kad nejaučia, 1,3 proc. - negalejo atsakyti.

Dirbdami nakti jaučia ar galbūt jaučia didesnę darbo įtampą 83,6 proc. gydytojų ir 65,6 proc. slaugytojų. Tai, kad darbas naktị kelia didesnę ịtampą ir yra tam tikras stresorius, nurodo keletas autoriu (Weinberg, et al., 2000; Fujino, et al., 2006; Wiedav, et al., 2006).

Daugiau nei pusė $(56,1$ proc.) medikų nurodè, kad dirbant naktį nèra galimybės pamiegoti, 38,1 proc. - kad yra ar galbūt yra tokia galimybè.

Dẻl galimybès pailsèti dirbant naktị slaugytojų ir gydytojų nuomonès išsiskyrè: kad yra ar galbūt yra galimybè pailsèti, teigè 55,8 proc. gydytojų ir 26,4 proc. slaugytojų. Tačiau su tuo, kad darbas naktị nèra labiau poilsis, o ne ịtampa, sutiko absoliuti dauguma medikų ( 97,1 proc.).

Daugiau nei pusè (51,3 proc.) medikų nurodè, kad dirbdami naktị vartoja įvairius stimuliatorius (kavą, arbatą, energinius gérimus, tabaką), 24,8 proc. tai daro kartais, 23,9 proc. stimuliatorių nevartoja. Gydytojų ir slaugytojų nuomonès dèl stimuliatorių vartojimo statistiškai patikimai nesiskyrè. 
Daugumai medikų (49,4 proc.) po naktinio darbo reikia 6-7 val. miego, kad atsistatytų fizinè ir psichinè būklè, 13,7 proc. pakanka 4-5 val. miego, o 36,9 proc. reikia miegoti 8 val. ir ilgiau. Slaugytojų fizinei ir psichinei būklei atstatyti pakanka mažiau miego nei gydytojams (2 pav.).

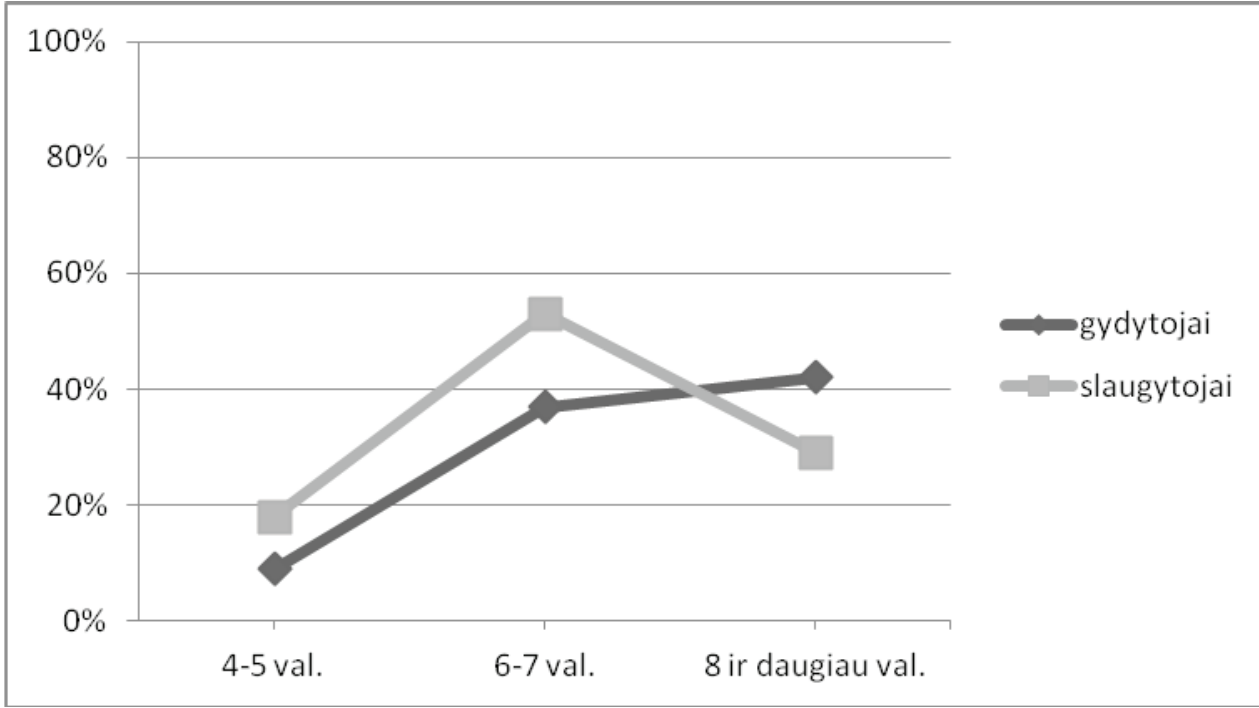

2 pav. Miego trukmè, būtina susigrąžinti fizinę ir psichinę būklę po naktinio darbo

Analizuota, ar medikai per 24 val. po naktinio darbo buvo patekę ị autoịvyki. 9,4 proc. nurodè, kad buvo (14,5 proc. gydytojų ir 6,0 proc. slaugytojų). Trečdalis medikų (35,4 proc.) teigè, kad dèl darbo naktį kyla problemų šeimoje, 13,5 proc. - kad galbūt kyla, pusè (49,9 proc.) - kad problemų šeimoje nekyla. Čia gydytojų ir slaugytojų nuomonès statistiškai patikimai nesiskyre. Turimi šeimoje vaikai iki $10 \mathrm{~m}$. amžiaus neturèjo įtakos problemoms dèl darbo naktį.

Medikų požiūriui ị naktinio darbo įtaką miegui, sveikatai ir šeimai lytis, amžius, socialinė padètis, išsilavinimas, šeiminè padètis, darbo profilis, specialybės ir naktinio darbo stažas bei gyvenamoji vieta ịtakos neturẻjo.

Absoliuti dauguma - 97,6 proc. medikų mano, kad naktinis darbas turi būti papildomai apmokamas.

Trečdalis (31,3 proc.) medikų mano, kad naktinis darbas gali būti rimta priežastis keisti darbo vietą, 28,2 proc. - kad galbūt gali būti priežastis ją keisti. Kas ketvirtas $(25,8$ proc.) medikas nemano, kad naktinis darbas gali būti rimta priežastis keisti darbo vietą. Tvirtai ịsitikinę, kad naktinis darbas yra rimta priežastis keisti darbo vietą, yra 39,4 proc. gydytojų ir 26,0 proc. slaugytojų (3 pav.). 


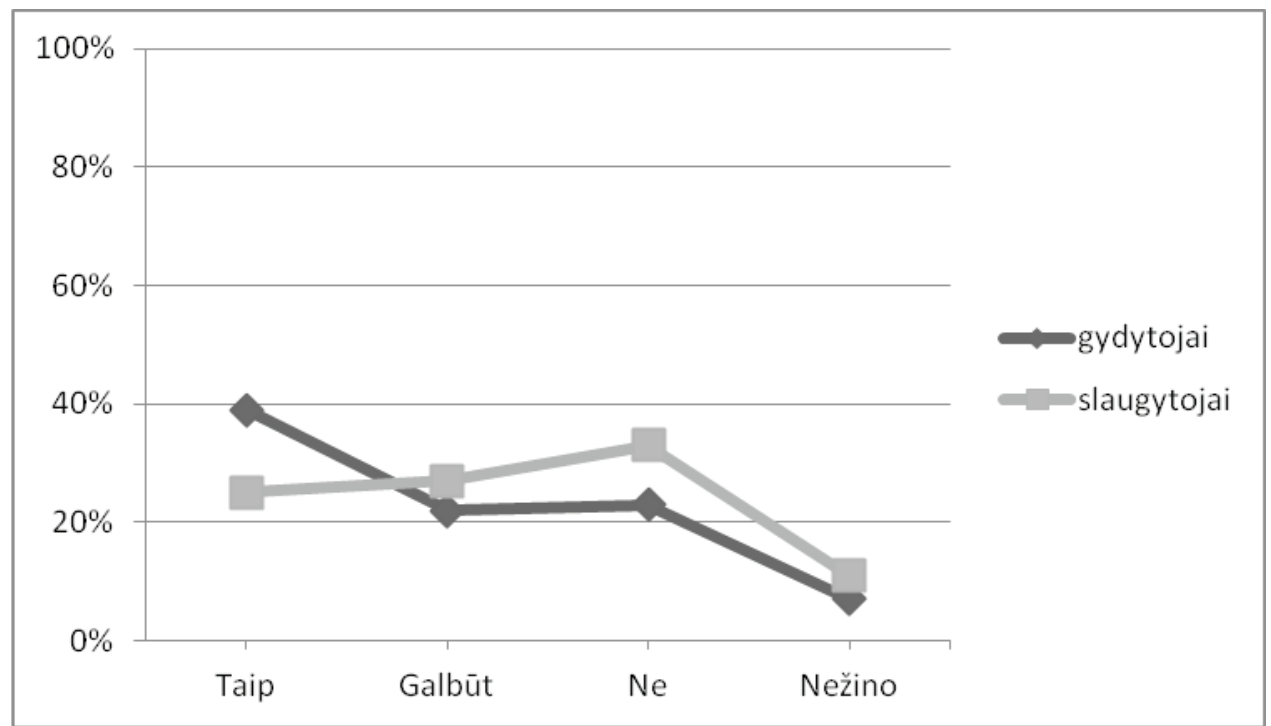

3 pav. Atsakymų i klausimą, ar naktinis darbas yra rimta priežastis keisti darbo vietą, pasiskirstymas

\section{Išvados}

1. Medikų - gydytojų ir slaugytojų - nuomonès beveik visais klausimais dèl naktinio darbo neturèjo statistiškai patikimų sąsajų su lytimi, amžiumi, socialine padètimi, išsilavinimu, šeimine padètimi, darbo profiliu, specialybès ir naktinio darbo stažu bei gyvenamąja vieta.

2. Dauguma medikų mano, kad naktinis darbas netapatus dieniniam, jis kelia tam tikrą įtampą, kenkia sveikatai ir, jei būtų galimybė, rinktųsi dieninį darbą.

3. Daugiau nei pusè medikų (59,5 proc.) mano, kad naktinis darbas gali būti ar galbūt gali būti rimta priežastis keisti darbo vietą.

4. Gydytojai jautresni darbui naktị nei slaugytojai: gydytojai labiau nei slaugytojai (85,5 proc. ir 46 proc.) dirbtų dieną, jie daugiau nei slaugytojai (93,9 proc. ir 58,8 proc.) rinktųsi dieninị darbą, jiems naktinis darbas dažniau nei slaugytojams (91,5 proc. ir 79,2 proc.) sutrikdo cirkadinị ritmą, gydytojams dažniau nei slaugytojams (50,3 proc. ir 25,6 proc.) dèl naktinio darbo kyla problemų šeimoje, jie dirbdami naktį jaučia didesnę įtampą nei slaugytojai ( 74,5 proc. ir 57,2 proc.).

Gauta 20150915

Pasirašyta spaudai 20151005 


\section{Literatūra}

Arnedt, J. T., Owens, J., Crouch, M., et al. (2005). Neurobehavioral performance of residents of for heavy night call us alcohol ingestion. JAMA 294: 1025-1033.

Bacon, S. L., Cambell, T. S., Arsenault, A., Lavoie, K. L. (2014). The impact of mood and anxiety disorders on incident hypertension at one year. International Journal of Hypertension 95: 30-94.

Brown, R. B., Brooks, J. (2002). Temporal landscape of night nursing. Journal of Advanced Nursing 39: 384-390.

Burgard, S. A., Lin, K. Y. (2013). Bad Jobs, Bad Health? How Work and Working Conditions Contribute to Health Disparities. American Behavioral Scientist 57: 1105-1127.

Campbell, A. M., Nilsson, K., Andersson, E. P. (2008). Night duty as an opportunity for learning. Journal of Advanced Nursing 62: 346-353.

Celik, S., Oztekin, D., Akyolcu, N., Jssever, H. (2005). Sleep disturbance: the patient care activities applied at the night shift in intensive care unit. Journal of Clinical Nursing 14: 102-106.

Coomber, R., Smith, D., McGuinness, D., et al. (2014). Foundation doctors working at night: what training opportunities exist? Medical Teacher 36: 632-638.

Dalton, M. A. (2013). Perceptions of the advanced nurse practitioner role in a hospital setting. British Journal of Nursing 22: 48-53.

Doyle, C., Lennox, L., Bell, D. (2013). A systematic review of evidence on the links between experience and clinical safety and effectiveness. British Medical Journal 3: 1-10.

Dumont, M. (2009). Controlled Patterns of Daytime Light Exposure Improve Circadian Adjustment in Simulated Night Work. Journal of Biological Rhythms 24: 427-437.

Fujino, Y., Tamakoshi, A., Inaba, Y., et al. (2006). A prospective cohort study of shift work and risk of ischemic heart disease in Japanese male workers. American Journal of Epidemiology 164: 18-135.

Galagher, P., McLean, P., Campbell, R., et al. (2009). Medical Training and hospital at night: an oxymoron? Medical Education 43: 1056-1061.

Hendey, G. W., Barth, B. E., Soliz, T. (2005). Overnight and post call error in medication orders. Academic Emergency Medicine 12: 629-634.

Hochschild, A., Machung, A. (2012). The second shift. Working families and revolution at home. New York, NY: Penguin Books.

Janušonis, V. (2005). Rizikos valdymas sveikatos priežiūros organizacijose. Klaipėda: S. Jokužio spaustuvè-leidykla.

Janušonis, V. (2008). Sveikata ir valdoma sveikatos priežiūra. Klaipèda: S. Jokužio spaustuvė-leidykla.

Janušonis, V., Kringelytė, G. (2009). Tinkama sveikatos priežiūra: socialinio streso vaidmuo. Sveikatos mokslai 19: $62-69$.

Jones, C. B. (2004). The costs of nurse turnover. Part 1: An economic perspective. Journal of Nursing Administration 34: 562-570.

Jones, C. B. (2005). The costs of nurse turnover. Part 2 Application of the nursing turnover cost calculation methodology. Journal of Nursing Administration 35: 41-49.

Kardelis, K. (2005). Mokslinių tyrimu metodologija ir metodai. Šiauliai: Lucilijus.

Khoddam, H., Metirdad, N., Peyrovi, A., et al. (2014). Knowledge translation in health care: a concept analysis. Medical Journal Islam Republic Iran 28: 98-98.

Kryger, M. H., Roth, T., Dement, W. C. (eds.) (2005). Principles and practice of sleep medicine. 4 the ed. Philadelphia: WB Saunders.

Landrigan, C. P., Rothschild, J. M., Cronin, J. W., et al. (2004). Effect of reducing interns' work hours on serious medical errors among interns in intensive care units. New England Journal of Medicine 351: 1838-1848.

Landro, L. (2008). Hospitals move to reduce risk of night shift. The Wall Street Journal 28: 1-5.

Lee, Y. Y., Lin, J. L. (2010). Do patient autonomy preferences matter? Linking patient - centered care to patient physician relationship and health outcomes. Social Science and Medicine 71: 1811-1818.

Lucini, D., Pagani, M. (2012). From stress to functional syndromes: An internist's point of view. European Journal of Internal Medicine 23: 295-301.

Marshall, N. L., Tracy, A. J. (2009). After the baby: Work - family conflict and working mothers' psychological health. Family Relations 58: 380-391.

Miller, A. D., Piro, C. C., Rudisill, C. N., et al. (2010). Night time and weekend medication error rates in an inpatient pediatric population. The Annals of Pharmacotherapy 44: 1739-1746. 
Muecke, S. (2005). Effects of rotating night shifts: literature review. Journal of Advanced Nursing 50: 433-439.

Niu, S. F., Chung, M. H., et al. (2013). Sleep Quality in Nurses: A Randomized Clinical Trial of Day and Night Shift Workers. Biological Research for Nursing 15: 273-279.

Novoselsky Persky, M. A., Yinnon, A. M., Freier-Dror, Y., Henskke-Bar-Meir, R. (2013). Communication between residents and attending doctors on call after hours. Journal of Evaluation in Clinical Practice 19: 1107-1112.

Obni, M., Johansson, P., Fridlund, B. (2004). Nursing care at might: an evaluation using the Night Nursing Care Instrument. Journal of Nursing Administration 47: 25-32.

Ruggiero, J. S., Redeker, N. S. (2014). Effects of Napping on Sleepiness and Sleep-Related Performance Deficits in Night - Shift Workers. A Systematic Review Biological Reserch for Nursing 16: 134-142.

Schernhammer, E., Laden, F., Speizer, F., et al. (2003). Night-shift work and risk of colorectal cancer in the Nurse's Health Study. Journal of the National Cancer Institute 95: 825-828.

Smith, M. (2007). From student to practicing nurses. American Journal of Nursing 10: 72A-72D.

Ulrich, B., Buerhaus, P., Donelan, K., et al. (2005). How RNs view the work environment: Results of a national survey of registered nurses. Journal of Nursing Administration 35: 389-396.

Van Dogen, H. P., Maislin, G., Mullington, J. M., Dinges, D. F. (2003). The cumulative cost of additional wakefulness: dose-response effects on neurobehavioral functions and sleep physiology from chronic sleep restriction and total sleep deprivation. Sleep 26: 117-126.

Weinberg, A., Creed, F. (2000). Stress and psychiatric disorder in health care professionals and hospital staff. Lancet 355: 533-537.

Weingart, S. N., Zhu J., Chiappetta L., et al. (2011). Hospitalized patients participation and its impact on quality of care and patient safety. International Journal for Quality in Health Care 23: 269-277.

Wieclav, J., Agerbo, E., Mortensen, P. B., Bonde, J. P. (2006). Risk of affective and stress related disorders among employees in humane service professions. Occupational and Environmental Medicine 63: 314-319.

\section{THE RIGHT HEALTH CARE: MEDICS’ NIGHT SHIFT WORK}

\section{Vinsas Janušonis}

Summary

The medics' (doctors, nurses) profession - one of the most associated to night shift. The aim of this study - to assess the medics' approach to night work in multiprofile hospitals of Lithuania. Materials and methods. A study carried out in six multiprofile hospitals of Lithuania from May to July of the year 2015. The study included 415 medics (135 physicians and 250 nurses). Information was collected via questionnaires (response rate $97 \%$ ), which was designed for the study.

Night shift work has been analysed in several related and summarized aspects: approach to night shift work as a phenomenon (1), the impact of night shift on the physiological needs, health and family (2), the interface of night shift work with the environment and work organization (3).

Examined the approaches to interface with gender, age, social situation, education, the family, the job profile, speciality and experience of night work, the place of residence. 
Statistical data analysis was done using programme SPSS 19.0 for Windows and "Microsoft Excel 2007".

Variable is considered statistically significant when $p$-value is less than 0.05 .

Results. Medics were divided in to two groups - doctors and nurses. There groups of respondents were analysed under the general demographic and social characteristics. The results of the study showed that majority of medics the night shift work estimate as different than day work, part - as the more complex and require more expertise.

Also, most of the tested persons asses the night shift as work to a greater tension and stress, affecting the health and the priority they attach to day work.

Conclusions. The medics' - physicians' and nurses' opinion mainly on all matters concerning night shift work had no statistically reliable link with gender, age, social situation, education, the family and job profile speciality and experience of night work, the place of residence.

Majority of respondents think night work is different than day work they will select day work if have such possibility.

More than half (58.5\%) of medics think night shift work may be a serious cause to change the workplace.

The doctors significantly more sensitive to night work than nurses. The doctors are better than nurses to work day ( $85.5 \%$ and $46 \%$ ), more of them compared to nurses will select day work (93.9\% and $58.8 \%$ ), doctors Circadian rhythm loss more likely than nurses $(91.5 \%$ and $46 \%$ ), night shift work causes doctors family problems more often than nurses family $(50.3 \%$ and $25.6 \%)$, doctors feel a greater tension and stress then nurses $(74.5 \%$ and $57.5 \%)$. 
